\title{
Restraints on competition in the Russian air passenger market
}

\author{
S. A. Lukyanov $v^{1,2,3}$, L.S. Ruzhanskaya ${ }^{2}$, E. S. Avramenko ${ }^{2}$, V. V.Stroev ${ }^{1}$ \\ ${ }^{1}$ State University of Management, 99, Ryazansky pr., Moscow, 109542, Russian Federation \\ ${ }^{2}$ Ural Federal University, Graduate School of Economics and Management, 19, Mira ul., Yekaterinburg, \\ 620000, Russian Federation \\ ${ }^{3}$ St. Petersburg State University, 7-9, Universitetskaya nab., St. Petersburg, 199034, Russian Federation
}

For citation: Lukyanov S. A., Ruzhanskaya L. S., Avramenko E. S., Stroev V. V. Restraints on competition in the Russian air passenger market. St Petersburg University Journal of Economic Studies, 2018, vol.34, issue 1, pp. 134-148. https://doi.org/10.21638/11701/spbu05.2018.107

This article discusses the results of a continuous study of Russian domestic air carriers conducted in 2006-2016 and analyzes the main barriers to entry into the passenger air travel market and their impact on competition in this field. There are significant structural barriers that prevent companies from entering this market. This situation challenges the existing concept and the idea of the domestic air transportation market as a quasi-competitive one. To describe the structure of the Russian passenger air transport market, we introduce the notion of "discrete competition," reflecting shifted density of market concentration towards small regional airlines. The latter are usually united by ownership mechanisms or affiliation with an airport. They possess considerable market power, but at the same time have an insignificant market share in the overall Russian passenger air market. Administrative barriers also play a crucial role in restraining competition. Furthermore, current institutional conditions are favourable for vertical 'airport - airline' integration which results in a fundamental transformation, as described by Williamson, and can be detrimental to competition. As our research findings have shown, there is a trade-off between existing vertically integrated structures in the air passenger market and public welfare.

Keywords: entry detergents, market structure, competition policy, discrete competition, antitrust regulation.

\section{Introduction}

Passenger air travel sector serves as one of the key indicators of the whole economic infrastructure development as the demand for air carriage reflects the population's welfare. A visible correlation between aviation development and air travel market in a country signifies economic, industrial, social, and institutional efficiency of the state policy. All these aspects make it especially interesting to analyse the air passenger market.

Among the most important economic issues related to the air passenger market is the problem of competition and the scale of state regulation that is appropriate for this sphere. In the USA, the Airline Deregulation Act (1978) [Schmalensee, 1977; Douglas, 1974; Anderson, 1984] led to positive changes and transformed the passenger air transportation market into an quasi-competitive or contestable. Quasi-competitive markets are characterized by a relatively high concentration and small deviation of prices from the competitive level due to a real risk of potential competitors' invasion.

(c) Санкт-Петербургский государственный университет, 2018 
Studies of the air passenger market have shown that in most Western markets there are clear distinctions between existing business models of passenger transportation such as VIP-flights, charter flights, connection flights, low cost flights etc. At the same time, mixed model prevail in the Russian air passenger market. In the Western countries, growth rates of air cargo transportation are higher than those of passenger transportation while the situation on the Russian market is directly opposite.

Our study is driven by the following objective to analyse the established structure of the Russian air passenger market.

The paper is structured in accordance with the abovementioned objective. Firstly, based on the data on all the airlines currently operating in Russia, we estimated the level of competition and demonstrated that the market structure of the Russian air passenger market (APM) is not quasi-competitive at the moment in contrast to air passenger market of Western Europe and the USA.

Issues of quasi-competition were also investigated in relation to large, capacious civil aviation markets, such as the US air transportation market [Seliverstov, 2016]. Unlike developed markets, those of emerging economies, such as Russia and the CIS countries, are characterized not by quasi-competition but rather by discrete competition [Lukyanov, Kislyak, 2007; Lukyanov, 2008; Lukyanov, Evtyukhov, 2010].

Secondly, we have identified the negative impact of vertical 'airport - airline' mergers on competition in this market and studied the positive effects that such vertical integration has on public welfare.

Finally, we revealed the most efficient strategies of entry into the APM to promote competition in this sector.

\section{Data and methodology}

The main source of information on the level of competition in the APM was a database of the Federal State Unitary Enterprise 'State Air Traffic Management Corporation' (further referred to as FSUE State ATM Corporation). We have analysed data on 355 Russian airlines which started their activity between 1991 and 2016. We have also used statistical materials and records of the Federal Air Transport Agency (Rosaviatsyia), Transport Clearing House, Federal Agency of Air Transport and the Ministry of Transport of the Russian Federation.

The official data were supplemented with the results of our own research which included questionnaire-based surveys and interviews with over one hundred and fifty experts from various Russian domestic airlines. The questionnaire comprised six modules:

- the first module asked the respondents about the market's structure, parameters and characteristics of the operating airlines;

- the second module asked the respondents to analyse accessibility of specific segments in this market in terms of their openness to new players and growth opportunities for old ones;

- the third module targeted at identifying factors which prevented potential players from entering this market;

- the fourth module complemented the third one and asked the respondents to classify barriers as structural-technological or behavioural;

- the fifth module aimed at studying the types of barriers in more detail; 
- in the sixth module, the hypothesis of overcoming the barriers described in the fifth module is tested. In the sixth module the respondents were asked to assess such forms as 'franchising', 'codeshare agreements', 'blocked space agreements', and 'shared services agreements'.

Thus, the first group of questions enabled us to analyse Russian APM's structure and the operating companies; the second one allowed identifying the most significant barriers to entry; the last group of questions made us understand how these barriers are being overcome.

\section{Competition between airlines in the Russian air passenger market}

Developed economies are often considered as examples of contestable or quasi-competitive markets [Baumol et al., 1982]. To what extent can the Russian air passenger market be characterized as contestable? According to Baumol, a contestable market is the market, the entrance to which is absolutely free, and the exit is absolutely costless' [Baumol, 1982]. This means that entrants are not discriminated in terms of production technologies and quality of the product in comparison to incumbents. Long run equilibrium in contestable markets is characterized by the fact that companies do not receive abnormal profits; prices are equal to marginal costs, which is typical for perfect competition. A market of perfect competition is always a contestable market but not vice versa. The market's contestability does not depend on its sectoral structure [Baumol, 1977]. Scale effect and effect of diversity can limit the number of companies to a small group of operating firms which are trying to minimize their expenses. However, they cannot afford to raise their prices above the marginal costs as otherwise this would enable a newcomer to gain an abnormal profit and would create stimuli for entering the market.

This model of competition has a number of criteria which any market should meet in order to be classified as contestable. The authors of the contestable market concept believe that these criteria are as follows:

1) free access to technologies and facilities enjoyed both by incumbent firms and entrants;

2) real threat of potential competition;

3) negligible sunk costs;

4) possibility of the 'hit and run' strategy (a company can enter the market and exit it after exhausting supernormal profits without having to bear any excessive costs).

Let us analyse whether these criteria are applicable to air travel markets, for example to the Russian one.

The first criterion, that is, free access to technologies owned by operating companies can be met by the majority of markets, including the APM. Apart from owning a fleet, a company should gain access to facilities and services of its base airport and other airports it has to deal with. Nevertheless, in the airline sector airports and local airlines often tend to merge preventing other companies from opening routes to new destinations via these airports.

The second criterion of a contestable market is realized by companies poaching other companies' routes when the air services prices rise. This is because airlines are constantly looking for ways to use their capital to improve profitability. 
The criterion of negligible sunk costs of entering the market can be met by the APM only with certain reservations. Sunk costs are incurred by companies and can no longer be recovered. Market contestability implies that sunk entry costs must be very low, almost insignificant. Baumol used the air passenger travel market as an example of a market with low sunk costs. This appears to be true at first sight. If a company has a fleet and a discrete flights schedule, it would not incur any extra expenses using the same fleet to open a new route. However, opening up new routes always leads to loss of value. For example, there will be costs of negotiating landing rights with an airport, fees for parking aircraft, advertising expenses etc. All these cost are sunk costs, and they account for a substantial share of the companies' overall costs.

The openness criterion is met by the air passenger market to even lesser extent. It is expected that a potential competitor can use any opportunity of profit-making (even short-term ones) since it can enter the market, make profit before prices change and then exit the market with no sunk costs. The incumbent firms, fearing penetration of new firms, will keep prices at a competitive level. Thus, the market, even if it is highly concentrated, will demonstrate competitive pricing.

The third and the fourth criteria are closely connected to each other: when investments are redeemable, a firm can sell its capital assets not cheaper than their market value. A different situation is observed if we take into account sunk costs. The higher the sunk costs, the longer a company has to stay in the market in order to get adequate returns and the less successful its 'hit and run' strategy can be.

In the case of charter flights, pricing depends on the number of passengers. This type of flights allows the intruder to operate without a substantial spend of resources. In their pricing policies, incumbent companies serving charter flights do not have to take into account new players, even if they snatch away some part of the market. A newcomer can realize its interests and run flights until an incumbent company starts changing its fares in order to push an entrant out of the market. It should be mentioned, however, that companies operating within the commercial aviation sector tend to react faster to entrants' pricing initiatives.

Even this preliminary analysis of the quasi-competition concept key theoretical criteria makes one doubt the fact that the Russian APM meets the necessary quality requirements of a contestable market. Let us describe the Russian APM's structure on the basis of descriptive statistics and conduct an econometric analysis of this market.

The Russian APM has the following characteristics. All airlines originated from 'Aeroflot - Soviet Airlines', the only national airline of the USSR. The collapse of this company resulted in emergence of 393 regional small independent companies (so-called 'babyflots'). They were either successors of the former civil aviation territorial departments or united aviation units. This determined their positions in the structure of an emerging airline market. These companies established their own route networks, base airports and fleets.

In case of European countries, formation of the airline market was initially based on competitive struggle. Therefore, it is not surprising that foreign markets have a much wider range of opportunities for building contestability-based models.

The Russian APM is rapidly changing. Since 2000, having overcome declining passenger traffic volumes, it began to grow on average by $10-15 \%$ a year (the annual GDP growth in Russia was 5-6\%). This period lasted till 2014 when the rates levelled off at 
$10.2 \%$. In the last five years, the volume of traffic has risen by more than $60 \%$. At the same time the number of carriers has been constantly decreasing (Table 1). On the one hand, this trend is indicative of the market expansion. On the other hand, it shows that separate companies are reinforcing their market positions.

Table 1. Overall indicators of the APM development in Russia (1993-2016)

\begin{tabular}{|c|c|c|c|c|c|}
\hline \multirow[b]{2}{*}{ Year } & \multirow{2}{*}{$\begin{array}{l}\text { Number of } \\
\text { airlines }\end{array}$} & \multirow{2}{*}{$\begin{array}{l}\text { Number of } \\
\text { certificates }\end{array}$} & \multirow{2}{*}{$\begin{array}{c}\text { Number of revoked } \\
\text { certificates }\end{array}$} & \multicolumn{2}{|c|}{ Passenger traffic, million people } \\
\hline & & & & Total & \begin{tabular}{|c|}
$\begin{array}{c}\text { Including international } \\
\text { airlines }\end{array}$ \\
\end{tabular} \\
\hline 1993 & 260 & 161 & 0 & - & - \\
\hline 1994 & 393 & 148 & 15 & - & - \\
\hline 1995 & 387 & 55 & 61 & - & - \\
\hline 1996 & 389 & 44 & 42 & 26.96 & 9.38 \\
\hline 1997 & 362 & 37 & 64 & 25.10 & 9.12 \\
\hline 1998 & 338 & 37 & 61 & 22.33 & 8.41 \\
\hline 1999 & 328 & 26 & 36 & 21.47 & 7.14 \\
\hline 2000 & 296 & 17 & 49 & 21.83 & 8.14 \\
\hline 2001 & 267 & 7 & 36 & 25.07 & 10.04 \\
\hline 2002 & 235 & 10 & 42 & 26.52 & 11.08 \\
\hline 2003 & 216 & 5 & 24 & 29.42 & 12.31 \\
\hline 2004 & 199 & 4 & 21 & 33.78 & 14.90 \\
\hline 2005 & 182 & 4 & 21 & 35.09 & 15.89 \\
\hline 2006 & 183 & 7 & 6 & 38.00 & 17.20 \\
\hline 2007 & 176 & 5 & 6 & 42.19 & 18.95 \\
\hline 2008 & 161 & 1 & 8 & 49.25 & 22.56 \\
\hline 2009 & 153 & 1 & 21 & 53.12 & 25.19 \\
\hline 2010 & 149 & 1 & 3 & 56.95 & 27.73 \\
\hline 2011 & 135 & 3 & 9 & 64.12 & 31.38 \\
\hline 2012 & 121 & 2 & 6 & 74.03 & 38.62 \\
\hline 2013 & 119 & 4 & 7 & 84.56 & 45.33 \\
\hline 2014 & 109 & 2 & 2 & 93.18 & 46.91 \\
\hline 2015 & 107 & 4 & 7 & 92.07 & 37.33 \\
\hline 2016 & 104 & 2 & 2 & 88.56 & 32.91 \\
\hline
\end{tabular}

Note: The table is based on the data provided by next source: The Federal Air Transport Agency. URL: http://www. favt.ru/dejatelnost-vozdushnye-perevozki-stat-pokazately/; http://www.favt.ru/public/materials//4/6/e/1/5/46e15e2a5e 762d0850aee65cc30ef696.pdf (accessed: 20.06.2017); Transport Clearing House. URL: https:/www.tch.ru/ru-ru/Pages/ Home.aspx (accessed: 20.06.2017); The FSUE State ATM Corporation. URL: http://gkovd.ru/deyatelnost/otchety/(accessed: 20.06.2017).

Since competition in the market is inherent, it is important to focus on the entry-exit processes because they influence the competition intensity in the sector. In terms of quantitative indicators, the market is very changeable.

It should be noted that most of the Russian airlines are either small companies with just a few aircrafts for private and business flights or companies providing services for specific sectors of national economy. According to the FSUE State ATM Corporation, at the end of 2016, 104 Russian airlines were registered. 
In 2016 seven certificates commercial civil aviation operators were issued and six ones were revoked (Table 1). Judging by the number of issued and revoked certificates, it can be inferred that barriers to entry are increasing while exit is relatively easy which is reflected in the rising number of revoked certificates. The APM as a competitive environment has a relatively high level of concentration. For instance, with 109 operating companies, 35 are responsible for $98.7 \%$ of the whole traffic. The five leaders (Aeroflot - Russian Airlines, Transaero, Siberia, Utair, and Ural Airlines) account for $62.3 \%$ of the traffic as of the end of 2016.

In equation (1) we have calculated the Herfindahl - Hirschman index measuring market concentration by taking into consideration equality (or inequality) of market shares distribution among companies.

$$
\mathrm{HHI}=\Sigma \mathrm{Si}^{2}
$$

where $\mathrm{Si}$ is the share of enterprise $\mathrm{i}$ (in per cent) in the overall output of the sector. The index value is 960.17 .

According to William Shepard's criteria, the identified index value shows that the APM in Russia is a normal oligopoly with no dominating company. Concentration indicators, however, being calculated at the general market level, cannot fully reflect competitive environment since boundaries of markets and industries do not coincide. Basically, a market means transporting passengers from point A to point B (with some reservations about the possibility of using connection routes). In relation to the market, concentration indicators change dramatically, to be more precise, they rise.

According to experts from the Antimonopoly Committee, specific problem of the air transportation market is presence of "pseudo competition" which hinders efficiency. Its existence is due to many small companies that are not able to compete because of small traffic volume as well as presence of a unified property or airport - airline affiliation. As a result, the antimonopoly authorities consider two main directions for the market structure development in the Russian air transport market. Firstly, more rational economic concentration in the market is required, but on condition that the market segment between airlines is not allowed on a territorial (route) or other basis. A comprehensive plan for civil aviation development, approved by the Chairman of the Russian Federation Government (No. MK-P17-08328, 12.05.01), provides for improvement of competitive relations in this sector of the economy. Secondly, selection of airports from composition of air enterprises can improve the market conditions. State measures aimed at restructuring and reforming civil aviation (Decree of the Russian Federation Government, June 24, 1998 No. 642) also stipulate reduction in the number of airlines including their unification as well as separation of airlines into independent market participants - airlines and airports. It is assumed that such rationalization of the air transportation system will reduce high level of operating and social costs in the market increasing in this way efficiency of civil aviation.

Competition in the Russian APM is discrete. Discrete competition can be described by (1) large number of market participants in general; (2) relatively small number of participants in separate spatial market segments with (3) high barriers to entry (into a specific spatial market segment).

Discrete competition in the Russian APM explained by access to specific route networks is impeded by low level of airport substitution for airlines as well as for customers. 
For instance, the airline Izhavia based in Izhevsk has a share of $0.6 \%$ in the overall volume of Russian passenger traffic and is not among the top thirty market leaders. On the routes this company serves it however plays either a dominant or a monopolistic role. This company's share on the routes Izhevsk - Anapa, Anapa - Izhevsk, Izhevsk - St. Petersburg, St. Petersburg - Izhevsk and some others is $100 \%$. On the route Izhevsk - Moscow, Moscow - Izhevsk this company occupies a dominant position.

Despite low values of the Herfindahl - Hirschman index, discrete character of competition makes the whole picture less optimistic. The discrete competition concept reflects a shift in market concentration towards smaller regional companies which are usually parts of 'airport - airline' mergers. These airlines have significant market power on the routes they serve while their market share in the overall traffic volume is small.

Descriptive statistics and the Herfindahl - Hirschman index of the Russian APM demonstrate that in the modern Russian economy there are no conditions for making the airline market contestable.

Let us test this assumption by applying econometric tools and surveying experts from Russian airlines.

Market competition in our model is determined by four indicators: free access to technologies for companies; existence of real potential competition threat; negligible sunk entry costs; realization of 'hit and run' strategy by entrants.

Our empirical study pursued two main objectives: we applied econometric methods to check whether the above-described independent variables can allow classifying the Russian APM as quasi-competitive. We applied the following econometric model to estimate the significance of quasi-competition in the APM:

$$
\operatorname{Pr}\left(Y_{i}=1\right)=F\left(\beta_{0}+\beta_{1} \text { FreeEntry }_{i}+\beta_{2} \text { Competition }_{i}+\beta_{3} \text { EntryCosts }_{i}+\beta_{4} \text { Strategy }_{i}\right),
$$

$Y_{i}$ - is existence (1) or absence (0) of quasi-competition on the APM;

$\mathrm{F}(\cdot)$ - is function of standard normal distribution.

Free Entry - is expert estimation of free access to technologies (from 0 to 10, where 0 means no access and 10 means that access is unrestricted);

Competition - is expert estimation of potential competition threat (from 0 to 10, where 0 no potential competition threat while 10 means that the threat is maximal);

Entry Costs - is expert estimation of sunk entry costs (from 0 to 10, where 0 means no sunk entry costs while 10 stands for insurmountable sunk entry costs);

Strategy - is expert estimation of the possibility of the 'hit and run' strategy in the airline market (from 0 to 10 , where 0 means that this strategy can be realized by any company while 10 implies that this strategy cannot be realized at all).

The research is empirically based on the results of a survey of 156 experts from the leading Russian and CIS airlines (apart from the Russian companies, the survey involved such companies as Air Astana and Skat (Kazakhstan); Air Armenia (Armenia); and Air Moldova (Moldova)).

The results of regression model estimation (2) are shown in Table 2.

Table 2 shows that all independent variables are statistically significant to classify the Russian APM as quasi-competitive or contestable. Therefore, compliance or non-compliance with the market contestability condition for new players is a pre-requisite for estimating quasi-competition in the APM. We estimated it by the descriptive statistics analysis. 
Table 2. Estimation quasi-competition role in the APM within the framework of a given theoretical model

\begin{tabular}{|l|c|c|}
\hline \multicolumn{1}{|c|}{ Independent variables } & \multicolumn{2}{c|}{ Coefficients } \\
\hline Constant & -0.018195 & $(0.624518)$ \\
\hline Free Entry & $0.013628^{* *}$ & $(5.768325)$ \\
\hline Competition & $0.103686^{* *}$ & $(4,587693)$ \\
\hline Entry Costs & $0,000318^{* *}$ & $(4.800122)$ \\
\hline Strategy & $-0.018195^{*}$ & $(-2.255429)$ \\
\hline Pseudo $R^{2}$ & \multicolumn{2}{|c|}{0,726} \\
\hline Number of observations & \multicolumn{2}{|c|}{156} \\
\hline
\end{tabular}

Note: The values of Z-statistics are given in brackets; ${ }^{*}$ means that the coefficient is significant on the $5 \%$ significance level; ${ }^{* *}$ means that the coefficient is significant on the $1 \%$ significance level.

In order to ensure conditions for effective competition, it is important to analyze market barriers, especially so-called endogenous ones (i.e., internal for the market) [Pakhomova, 2008].

The results of a questionnaire-based survey showed significant discrepancy between new and old players in terms of technology access. This discrepancy is primarily determined by lack of access to technologies experienced by newcomers. Almost all respondents $(94 \%)$ pointed out that it is difficult to obtain a certificate for urgent and routine aviation equipment maintenance and conducting an in-house overhaul essential for operating in this market. Moreover, there can be problems with specific technologies, for instance, with those of flight data processing and analysis. According to the Federal Air Transport Agency, such processing should be done for no less than $90 \%$ of flights. Until recently, there were only two Russian companies with such licenses: Aeroflot - Russian Airlines and S7 - Siberia. Therefore, we can conclude that APM is an market with significant structural and technological barriers to entry.

Estimating the real threat of potential competition, it should be mentioned that since 1990 there has been a large number of 'entries' (acquiring certificates). For instance, according to the FSUE State ATM Corporation, in 2006 there were thirty-three entries out of which only seven managed to obtain operator's certificates for application of aviation equipment. Only one company (Sky Express) can compete with existing players. All respondents agreed that there are considerable administrative barriers to entry. Such barriers include high transaction costs, e. g., informal payments to bureaucrats to be allowed to operate in a specific market, to be provided with slots (arrival / departure times), etc. High administrative barriers reduce potential competitors threat.

$98 \%$ of experts characterized this market as an market with a very high capital-output ratio. Sunk costs account for a large part of this ratio and are determined by a high degree of resources specificity. An essential component of sunk costs is transaction expenses (for example, informal payments to bureaucrats can hardly be classified as returnable). Our interviews with experts have provided much evidence on the Russian APM having extremely high level of sunk costs. Therefore, appearance of new airlines very "undesirable". Administrative measures are much more frequently used for this purpose than economic competition mechanisms. Administrative barriers lead to high transaction costs.

Comparison of the cost structure of Russian and international airlines reveals considerable sunk costs faced by companies in the Russian airline sector. In spite of different 
approaches to costs classification, in both cases the costs of technical, aeronautical and airport maintenance and lease payments account for a substantial proportion of expenses.

According to Baumol, the 'hit and run' strategy in the context of airline market means that it is relatively easy to organize routes from point A to point B. Within the framework of our research, however, this strategy is seen as comparatively easy capital circulation. Estimating chances of entrants to realize the 'hit and run' strategy in the Russian APM, all experts pointed out that it is impossible to transfer capital from one market sector to another. For example, in the Russian airline market there is no airport substitution for companies as well as for passengers. The pre-requisite for airports substitution is their equal availability for passengers (that is, how easy and convenient it is for passengers to get from one airport to another) and opportunity to use a given airport as a base for airlines. The latter is determined by the airport's class. The airport must also be certified in order to receive and maintain different types of aviation equipment, to serve flights to specific destinations, to provide the required airport maintenance of aircrafts, etc.

In addition, another serious constraint for realization of the 'hit and run' strategy is high sunk costs determining length of stay in this market. Therefore, it can be inferred that chances for realizing the 'hit and run' strategy in the Russian airline sector are extremely low.

The econometric analysis has demonstrated that all criteria of quasi-competition (2) are met meaning that this sector can be characterized as a quasi-competitive. However, assessment of descriptive statistics on these four independent equation variables (2) shows that the Russian APM does not comply with the contestability criterion.

Our study revealed a contradiction in the use of quantitative and qualitative methods for analyzing markets. An attempt to formalize evaluation criteria for the use of quantitative research methods, such as regression model estimation (2), led to a loss of specific market characteristics revealed in the course of qualitative research (expert interviews). As a result of descriptive analysis, we conclude that APM is characterized as a market with discrete competition. Thus, an important methodological conclusion is achieved: not all markets can be analyzed using only quantitative methods. With the APM case, it was shown that a combination of quantitative and qualitative research tools is needed to study the completeness of the market characteristics.

Theoretical and empirical analysis of this market has demonstrated that there are significant entry barriers. The market structure is best described by using the term 'discrete competition' [Lukyanov, Kislyak, 2007; Lukyanov, 2008; Lukyanov, Evtyukhov, 2010].

Discrete competition has three main dimensions: large number of participants in general; relatively small number of participants in separate spatial market segments, and high barriers to entry (into a specific spatial market segment).

\section{Ambivalent impact of vertical integration on public welfare: airport as a natural monopoly}

According to our analysis of the Russian APM, vertical mergers 'airport - airline' is widely spread in some regions. This allows considering characteristics of a natural monopoly which is the airport itself as the core of this structure.

Airports can be classified as enterprises of infrastructural sector. Airports concentrate relative monopoly power in specific areas. In favourable situation, inhabitants of a 
large urban area can have access to two airports but sometimes there is only one available airport. Airports' activities cause network effects and are determined by them. Airports serve as central hubs of the network in which passengers can connect to other flights. Traditionally, a natural monopoly was defined based on technological approach as a firm with a production function demonstrating positive returns on scale regardless of its output. Therefore, decreasing average costs typical of all infrastructural enterprises, serve as the main criterion of natural monopoly. Modern technologies of aircraft landing and those of maintaining runway are closely connected. Application of some technologies implies economies of scale and diversity, which is characteristic of airports. The larger the new terminal, the lower the cost of passenger's service. Thus, construction of large terminals provides economies of scale until the profits start to decline due to the increasing traffic. If one such terminal can satisfy all the demand, competitors will be left with nothing. This process also involves economies of diversity: the same runways can be used for transporting passengers and cargo. Companies with dominant positions can offer lower prices than their smaller competitors. Nevertheless, in the situation of increasing economies of scale it may be necessary to introduce regulations in order to limit these advantages of major companies leading to their growing market power. Market power is used by firms to set excessive prices, resulting in non-optimal resource distribution.

Modern technological organizational approach to understanding natural monopoly focuses on conditions for minimizing regulation of powerful companies. The theory of contestable markets proposed by Baumol, Panzar, and Willig had a great impact on deregulation in different sectors and on the understanding of the natural monopoly phenomenon. The technological organizational approach defines a situation when subadditivity of a costs function makes existence of one company more profitable than existence of many of them. Adherents of this approach consider an market to be natural monopoly if the costs function remains sub additive at all levels of production. In its turn, subadditivity means that if total production output of $\mathrm{n}$ firms is $\mathrm{Q}$, their combined costs for the overall production will always be higher than the costs of one firm which has the production output Q. Subadditivity can emerge due to impact of technological determinants. From the point of view of the contestable market theory, it results from organizational factors. In the situation of costs subadditivity, one large company can operate more efficiently than many smaller ones. Baumol used the concept of global costs subadditivity which allows describing a situation of a single-product or a multi-product natural monopoly [Baumol et al., 1982]. An airport providing multiple services can be characterized as a multi-product company. Therefore, for a multi-product company costs subadditivity function will can be summarized as follows:

$$
T C\left(q_{1}, \ldots, q_{m}\right) \leq T C_{1}\left(q_{1}\right)+\ldots+T C_{m}\left(q_{m}\right),
$$

where $T C\left(q_{1}, \ldots, q_{m}\right)$ is the cost function describing production of a products combination; $T C i(q i)$ is the cost function describing the costs of producing each product separately.

Subadditivity means that in the case of negative returns, joint production of two products by one company will be a more efficient option compared to separate production. However, M. Jamison demonstrated that global subadditivity is not sufficient but rather necessary requirement for a natural monopoly to exist [Jamison, 1997]. Even if airport services and air transportation are profitable from the public welfare point of view in general (multi-product subadditivity), it does not mean that from the customers' point 
of view the model with multiple airlines having access to the airport infrastructure would not be more preferable. Even if the total costs are higher, this will not necessarily imply higher prices. Technological improvements can enable competing companies to offer their customers alternative services. In this case, competition will spread among the airline companies. It is much more difficult to create several competing airports at the same territory. Moreover, since these airports might have different specializations, the fact of their existence does not guarantee competition in the corresponding services market.

Transaction costs approach is based on supposition that the higher is the level of assets specificity, the more stimuli there are for economic agents to organize their transactions in-house instead of doing so in the market. Elements of network structures in natural monopolies are characterized by high assets specificity, which means that these assets are practically impossible to apply in any other sphere. The costs of such assets are irreversible: they cannot be used in any other domain and they cannot be compensated if the firm decides to exit this market. The above-described theory is widely used for explaining vertical integration. From this standpoint, vertical integration including network structures is what distinguishes a natural monopoly. Therefore, the concept of natural monopoly is applied to vertically integrated structures. Specific assets and large investments in airports lead to situation when services are supplied by an integrated monopoly.

While in developed countries services that are not directly related to aviation bring up to $80 \%$ of the profit (restaurants, hotels, trade, parking spaces, etc.), in Russia they account for only $20 \%$. The main share of companies' funds is invested into air transportation business which leaves almost nothing for reconstruction and development of the company's infrastructure.

Attracting investors to develop ground infrastructure turns out to be a challenging task due to risks of inappropriate use of funds, lack of transparency in the joint aviation enterprise operations, necessity to merge two businesses, etc. At the same time, investors are primarily interested in the airport as an object of their investments. They rarely consider airline companies. Therefore, one can conclude that airports have characteristics of a natural monopoly.

\section{Ambivalent impact of vertical integration on public welfare: consequences of the mergers of airports and air carriers}

Vertical integration/separation of a natural monopoly and potentially competitive components may exert ambivalent impact on public welfare. Some economists support the idea of such disintegration while others are against it. Supporters put forward the following arguments: operations of an airport and an airline company will become more transparent which is extremely desirable for investment attraction; conflict between airline's and airport's targets will be eliminated. In case of disintegration, management of the companies will have to search for other opportunities to reduce costs and other sources of profit. Therefore, disintegration will create better conditions for competition. Opponents of disintegration provide the following argument: unity of the companies allows them to achieve better profitability. However, when profitability is achieved through redistribution of financial flows, the company loses control over efficiency of its businesses. Moreover, each business has to have sufficient profitability of its own. The company can set lower prices than its competitors. It is true that for many destinations airlines which have their 'own' airports can afford to set their prices lower than competitors due to low costs. At the 
same time, it should be taken into account that this advantage has an ambivalent nature: an airport subsidizes airlines but does not develop its own business. Being advantageous for the carrier, this can become an obstacle for the airport. Another argument for vertical integration is that it facilitates resolution of conflicts between participants of the air transportation market. However, clearly defined procedures of interaction between the airport and carriers can address this problem in a more efficient way. Evidence has shown that market mechanisms are more efficient in solving communication problems.

As our empirical observations have revealed, each year anti-monopoly authorities initiate about fifty proceedings for investigating evidence of restrains being put on competition in the airline market and airport operations. Most of such cases were associated with breaches of articles 5 and 17 of the 'Law on Competition and Restriction of Monopolistic Activities in Product Markets' [Williamson, 1985]. According to the anti-monopoly authorities, specific problem of this market is 'pseudocompetition' which is not conducive to any positive results. There are two factors behind pseudocompetition: first is abundance of small carriers which are incapable of competing with larger companies due to their small traffic volumes; second is existence of vertical 'airport - airline' mergers. Therefore, antimonopoly authorities believe that there are two main directions of development of market infrastructure in the Russian air passenger market.

Firstly, it is necessary to develop more rational economic concentration in the market, preventing market sharing among the air carriers based on the territorial (route-related) or any other principle. The Comprehensive Plan of Civil Aviation Development, approved by the Chairman of the Russian Federation Government (as of 12.05.2001 №17-083 28), explicitly provides for a need to stimulate competitive relationships in this sector.

Secondly, it is essential to improve the situation in the air travel market by demerging airports from aviation enterprises. The 'Government Measures of Restructuring and Reformation of Civil Aviation’ (Russian Government Decree of 24.06.1998 № 642) are also targeted at reducing the number of airlines.

It is expected that these measures will rationalize the air travel structure and will reduce operational costs in the market as well as social costs by enhancing general efficiency of this sector.

The process of the Russian airline market demonopolization (disintegration of aviation enterprises and separation of airports as independent businesses) started in the first half of the 1990s but the demonopolization rates have increased only in recent years. What is more, some of them underwent bankruptcy processes. The practice of breaking vertically integrated 'airport - airline' chains and replacing them with 'airline - efficient owner' chains in the Russian context [Coase, 1937] proved to be detrimental to the route network, especially, to regional routes which are traditionally unprofitable and which used to be subsidized at the expense of more profitable 'central' destinations and profits from airport operations.

The consequences of disintegration can be described in terms of public welfare ${ }^{1}$. At a regional level, considering such specific criteria as mobility of labour force and other resources and employment rate in the market-specific market, consequences of such disintegration can be estimated as negative. Reductions in the route network and traffic volume lead to a considerable fall in the labour force mobility, in the accessibility of remote regions, and in employment of the flight staff.

${ }^{1}$ Although there is a new law which has recently come into force, the authors of this article rely on the old law since it corresponds to the period when our empirical data were gathered. 
As a result of disintegration, when new and more efficient owners replace the old ones, it should allegedly lead to lower passenger fares, but this is still a debatable question. One of the arguments in favour of disintegration is that in the 'airport - airline' merger customers have to pay monopoly prices which is a negative effect (in the terms of public welfare it is the customer's loss). This situation is theoretically possible.

However, when large and efficient airlines occupy vacant places left after the collapse of the vertical 'airport - airline' merger, they tend to push smaller and less competitive companies out of the market which leads to increasing concentration and possible growth in passenger tariffs.

Disintegration of an 'airport - airline' merger does not provide any explicitly positive effect. An inefficient company from a vertically organized 'airport - airline' structure is replaced by an efficient company with market power. As a result, the latter occupies a monopolistic position, which in turn influences new 'monopoly' power. This causes a severe reduction in the route network, unemployment among the flight staff of the company which left the sector, and reduced accessibility of airlines resulting in growing social tension.

Another impactful factor preventing efficient separation of vertically integrated 'airport - airline' structures and efficient operation of players in this market is the low level of airports substitution for companies as well as for passengers. Recently, the aerodrome network serving local airlines has shrunk almost six times, a number of aerodromes and airlines which connected Russian regions to the country's central part were closed altogether. As a result, over twelve million people do not have all-year access to air transportation. According to the Federal Air Transport Agency, the number of aerodromes in Russia dropped from 1,302 in 1992 to 352 in 2016 [Federal Air Transport Agency...]. Technical and technological levels of aerodromes ground equipment also leaves much to be desired.

Only $59 \%$ of aerodromes have improved runways. $70 \%$ of aerodromes were built over twenty years ago and most of them are in need for reconstruction. In the Russian Federation there are only sixty-two airports which have federal status and form the core network of the Russian civil aviation [Federal Air Transport Agency...]. Substitution of airports allows airlines to reallocate their resources more effectively and to optimize both passenger and cargo traffic, which is one of the most essential prerequisites for meeting such quasi-competition criterion as the possibility of realizing the 'hit and run' strategy.

\section{Conclusion}

Based on the results of the Russian domestic carriers study conducted in 2006-2014, the article describes the structure of the Russian air passenger market and its key characteristics as a quasi-competitive market. The authors also analysed impact of disintegration of vertically integrated 'airport - airline' structures on the regional public welfare. Econometric methods were used to estimate the strategies of overcoming the entry barriers. Our findings indicate that there are significant structural, technological and behavioural market-specific barriers to entry into the Russian air passenger market which makes us doubt the existence of quasi-competition in this sector. Our empirical study of entry barriers has shown that in the Russian air passenger market administrative barriers are the most considerable factor impeding competition.

Discrete competition describes the Russian air passenger market because the market is dominated by small regional companies. These companies tend to be a part of a verti- 
cally integrated 'airport - airline' entity, they are monopolists on certain routes, but they occupy a small fraction of the total volume of passenger transportation.

We found in the regional markets the merger of airlines and home airports, which leads to additional monopolization. Our analysis showed that the relationship between such vertically integrated structures and public welfare is ambivalent. Firstly, disruption of vertical mergers often leads to a new 'efficient' monopoly dominating the market and using monopoly price formation. Secondly, disintegration of vertical structures often results in such negative effects as a considerable decrease in the passenger flow and in the labor force mobility; growing unemployment in the air travel market.

\section{References}

Anderson J. Identification of Interactive Behavior in Air Service Markets: 1973-76. The Journal of Industrial Economics, 1984, vol.32, no.4, pp.91-106.

Baumol W. J. Contestable Markets: An Uprising in the Theory of Industry Structure. The American Economic Review, 1982, vol. 72, no. 1, pp. 1-15.

Baumol W. J. On the Proper Cost Tests for Natural Monopoly in a Multiproduct Industry. American Economic Review, 1977, vol. 67, iss. 5, pp. 809-822.

Baumol W.J., Panzar J.C., Willig R. D. Contestable Markets and the Theory of Industry Structure. New York, Harcourt Brace Jovanovich, 1982, 510 p.

Caves R. Air Transport and its regulators. Cambridge: Harvard University Press, 1962. xi +479 p.

Coase R. The Nature of the Firm. Economica, n.s., 1937, vol. 4, pp. 386-405.

Douglas G., Miller J. Quality, Competition, Industry Equilibrium, and Efficiency in the Price Constrained Air Market. American Economic Review, 1974, September, no. 6, pp. 217-240.

Federal'noe agentstvo vozdushnogo transporta [Federal Air Transport Agency]. Available at: http://www.favt.ru/ dejatelnost-vozdushnye-perevozki-stat-pokazately/; http://www.favt.ru/public/materials//4/6/e/1/5/46e1 5e2a5e762d0850aee65cc30ef696.pdf (accessed: 20.06.2017). (In Russian)

Jamison M. A. A Further Look at Proper Tests for Natural monopoly. University of Florida: PURC, 1997, pp. 330342.

Lukyanov S. Otsenka znachimosti otraslevykh vkhodnykh bar'erov kak instrumenta ogranicheniia konkurentsii [Eestimation of the importance of industry entry barriers as a tool to limit competition]. Problemy sovremennoi ekonomiki [Problems of Modern Economy], 2008, no. 3, pp. 194-198. (In Russian)

Lukyanov S. Aviatsionnye passazhirskie perevozki: sovremennoe sostoianie rossiiskogo rynka i stran SNG [The Market of aviation passenger transport. The modern state in Russia and CIS countries]. ECO, 2008, no. 10, pp. 91-106. (In Russian)

Lukyanov S., Evtyukhov S. Globalizatsiia mirovoi ekonomiki i vnedrenie konkurentsii na reguliruemykh rynkakh: praktika empiricheskogo analiza [Competition in regulated markets in the globalization context]. Problemy sovremennoi ekonomiki [Problems of Modern Economy], 2010, no. 4. pp. 84-86. (In Russian)

Lukyanov S., Kislyak N. Otraslevye bar'ery vkhoda kak vazhneishii instrument politiki ogranicheniia konkurentsii [Industry entry barriers as the most important instrument of the policy of restriction of competition]. Voprosi economiki, 2007, no. 2, pp.101-110. (In Russian)

Pakhomova N. V. Sovremennaia politika v oblasti konkurentsii: teoreticheskii analiz i opyt realizatsii (primer ES-Rossiia) [Modern competition policy: a theoretical analysis and experience of implementation (example EU-Russia)]. Vestnik of Saint Petersburg University. Series 5. Economy. 2008, no. 2, pp.3-24. (In Russian)

Schmalensee R. Comparative Static Properties of Regulated Airline Oligopolies. Bell Journal of Economics. 1977, Aut., no. 8, pp.312-339.

Selivestrov D. A. Kvazikonkurentsiia na rynke vozdushnykh perevozok [Quasi-competition in the air transportation market]. Sovremennaia konkurentsiia [Modern competition], 2016, vol. 10, no.6, pp.36-48. (in Russian)

Williamson O. E. The Economic Institutions of Capitalism: Firms, Markets, Relational Contracting. New York: The Free Press, 1985, pp.609-612.

Received: 17.05.2017

Accepted: 13.12.2017 
Author's information:

Sergey A. Lukyanov - Doctor of Economics, Professor; s.lukyanov@mail.ru

Liudmila S. Ruzhanskaya - Doctor of Economics, Professor; l.s.ruzhanskaya@urfu.ru

Elena S. Avramenko - PhD in Economics, Associate Professor; e.s.avramenko@urfu.ru

Vladimir V. Stroev - Doctor of Economics, Professor; vv_stroev@guu.ru

\section{Ограничения конкуренции на российском рынке пассажирских авиаперевозок}

С. А. Лукьянов ${ }^{1,2,3}$, Л. С. Ружанская ${ }^{2}$, Е. С. Авраменко ${ }^{2}$, В. В. Строев ${ }^{1}$

${ }^{1}$ Государственный университет управления,

Российская Федерация, 109542, Москва, Рязанский пр., 99

2 Уральский федеральный университет, Высшая школа экономики и менеджмента, Российская Федерация, 620000, Екатеринбург, ул. Мира, 19

${ }^{3}$ Санкт-Петербургский государственный университет,

Российская Федерация, 199034, Санкт-Петербург, Университетская наб., 7-9

Для цитирования: Lukyanov S. A., Ruzhanskaya L.S., Avramenko E. S., Stroev V.V. Restraints on competition in the Russian air passenger market // Вестник СПбГУ. Экономика. 2018. Т. 34. Вып. 1. C. 134-148. https://doi.org/10.21638/11701/spbu05.2018.107

В данной статье рассматриваются результаты анализа структуры отечественных авиаперевозчиков, который проводился с 2006 по 2016 г., а также анализируются основные барьеры для входа на рынок пассажирских авиаперевозок и их влияние на конкуренцию на этом рынке. Делается вывод о том, что существуют значительные технологические и поведенческие барьеры, которые являются существенными препятствиями для входа новых компаний на рынок. Эта ситуация бросает вызов существующей концепции и представлению об отечественном рынке авиаперевозок как квазиконкурентному рынку. Для описания структуры российского рынка пассажирских авиаперевозок мы вводим понятие дискретной конкуренции, отражающее смещенную плотность концентрации рынка в сторону небольших региональных авиакомпаний. Последние обычно объединяются механизмами собственности или принадлежностью к аэропорту. Они обладают значительной рыночной властью, но в то же время имеют незначительную долю на рынке российского пассажирского авиаперевозок. Было обнаружено, что административные барьеры играют решающую роль в сдерживании конкуренции. Кроме того, нынешние институциональные условия благоприятны для вертикальной интеграции «аэропорт - авиакомпания», что приводит к фундаментальной трансформации, как описано Уильямсоном, и может нанести ущерб конкуренции. Как показали наши результаты исследований, существует компромисс между вертикально интегрированными структурами на рынке пассажирских авиаперевозок и общественным благосостоянием.

Ключевые слова: входные барьеры, структура рынка, дискретная конкуренция, конкурентная политика, антимонопольное регулирование.

Контактная информация:

Лукьянов Сергей Александрович - д-р экон. наук, проф.; s.lukyanov@mail.ru Ружанская Людмила Станиславовна - д-р экон. наук, проф.; l.s.ruzhanskaya@urfu.ru Авраменко Елена Семеновна - канд. экон. наук, доц.; е.s.avramenko@urfu.ru Строев Владимир Витальевич - д-р экон. наук, проф.; vv_stroev@guu.ru 